de vrige medier. Det leverer fortrinsvis en type medieoplevelser, som de фvrige medier er afskåret fra at give, fordi de ikke kan arbejde i billeder. Til gengald leverer disse medier så andre ting, som også kan have vardi: en lobende information og debat om det lokale samfunds begivenheder og problemer.

Denne programpolitik kan give vanskeligheder. Fra de lokale politikere begynder der at lyde toner som: TV-Syd mangler narhed og aktualitet, man har ikke haft fingeren på pulsen.

Seernes dom vil sikkert ikke vare nær så hård, for seerne har ikke det samme kære forhold til politik som politikere har. Pg den anden side interesserer man sig for nyheder - ikke mindst lokale nyheder.

Der har imidlertid heller ikke været så mange der har set TV-Syd, og det har været en afgфrende arsag til at det endnu ikke er blevet belyst hvad seerne mener om de enkel te dele af TV-Syd's programpolitik. De lovende seertal til TV-Syd's af tenmagasin om tirsdagen har ændret ved denne situation, så der nu skulle være mulighed for at fa et nuanceret billede af seernes stillingtagen til TV-Syd.

Den 11. september 1984 begyndte TV-Syd atter at sende efter sommerferien. Historien fortsætter.

\title{
Noter
}

1. Referat af Radiorådsmødet den $30.11 .1982, \mathrm{p} .465$.

2. Rapport om ligangs attel se af Regional-TV-forsøget. Danmarks R adio: 1982-0509.

3. Der er redegjort udførligt for begrundelsen for dette synspunkt i Carsten Hansen, TV-Syd's seertal, sendetid og popularitet. Arbejdspapir nr. 22. Aabenraa: Insti tut for gr æns eregionsf orskning, 1984, ss ff.

Carsten Hansen er ansat på Institut for Grænseregionsforskning, hvor han varetager følgef orskning af TV-Syd. 


\section{NIRRRADIO - UDFORSKNING AF ET ALTERNATIV}

\section{Af Ole Prehn}

Mens det i de fleste lande med borgerligt-demokratisk tilsnit er et hævdvundet princip, at retten til at kommunikere horer under de fundamentale menneskerettigheder, er det først de senere ar, at dette princip er blevet giort gældende $\mathrm{I}$ forhold til de elektroniske medier. Organiseringen af disse har hidtil hvilet p\&̊ $\emptyset$ konomisk og politisk betingede vilkăr, som har fremmet medie-monopolernes og envejskommunikationens dominans hinsides de demokratiske princippers egalitære visioner.

En rakke bestræbelser, som de fx finder udtryk $\mathrm{i}$ den sakaldte MacBride-rapport (Many Voices - One World), går derfor ud pa at realisere dette princip om alles muligheder for at indhente og af give information - dvs. kommunikere på lige fod og ligevær digt. I sin bog "Technologies of Freedom" (1983) fremhæver Ithiel de Sola Pool, at den storste forhindring i dette projekt er inadakvate mediepolitiske og telekommunikationspolitiske reguleringstiltag, som i bestr æbelsen for at forhindre altdominerende monopoldannelser, har gjort en frigorende og demokratiserende brug af de nye medier umulig.

De Sola Pool ligger på denne måde $i$ en vis forstand på linje med de str $\phi$ mninger, som i slutningen af 1960-erne ytrede stor tiltro til de nye elektroniske mediers demokratiserende og politiserende muligheder.

Troen pa de nye muligheder havde to udgangspunkter: for det første praktiske tiltag i USA og Canada, hvor henholds vis ini tiativgrupper og institutioner fors $\phi$ gte at skabe alternativer til de eksisterende medier enten som lokale, græsrodsradioer eller som sociale eksperimenter, hvor de mest kendte er det canadiske filminsti tuts "Challenge for Change". Og for det andet $i$ en europæisk sammenhang mere teoretiske overvejelser b.a. med baggrund 1 Brechts radioteori, hvis diktum jo er, at alle modtagere samtidig kan og $b \phi r$ vare afsendere. Mest markant kom disse synspunkter til orde i Hans Magnus Enzensbergers "Byggesæt til en medieteori" fra 1970, hvori der specielt blev gjort op med venstrefløjens påståede mediepuritanisme ud fra en tro pa de elektroniske mediers mobiliserende og politiserende kraft. Inspirationen fra Nordamerika kombineret med det mediepolitiske tidehverv i 
Vesteuropa satte derfor public access p\& 1970-ernes dagsorden, samtidig med at en stigende legitimationskrise som følge af de senkapitalistiske samfunds øgede centralisering og kompleksitet kombineret med et stigende ubehag ved de store, pa venstrefløjen hidtil kanoniserede offentligretslige mediemonopoler gjorde decentraliserings-tiltag opportune. At public access saledes blev en central problemstilling skyldes derfor de paradoksale sammenfald af interesser for radikale al ternativer hos "det nye venstre" og establishmentets legitimationsproblemer. Interessen var således langt fra entydigt noget velfardsf ænomen, som $\mathrm{fx}$ hæevdet hos Lewin (1984), hvilket en rakke af de 1 1970-erne igangsatte for $\$ g$ så indlysende vidner om (cf, Prehn, 1981).

Internationalt er det endvidere karakteristisk, at mediealternativerne nzesten endimensionalt reflekterer den aktuelle mediesituation på et givet sted, således at narradioerne I USA og England opstod som alternativer til de ekspanderende kommercielle lokalradioer og derfor programpolitisk sigtede mod et indhold, som var præget af information og debat, som helt var udelukket fra main-streamradioerne, mens man i Vesteuropa samtidig så pirat-radioer, som med netop en main-stream-policy med popmusik, reklamer og DJ-jargon forsøgte sig som al ternativer til de finkulturelt orienterede monopoler.

De meget forskelligartede grundlag, som narradioerne i dag eksisterer p\&, blev tydeligt belyst pa den f $\phi$ rste internationale nærradiokonferecne, som blev afholdt i Montreal 1983 (cf. Prehn, 1983 og Lewis, 1984). Begrebet nærradio, som pa engelsk har betegnelsen community radio, som mere precist end det danske begreb peger på, at der både kan være tale om geografisk eller interessebetinget grundlag for radiovirksomheden, er derfor et fanomen, som kun kan betragtes $i$ forhold til en specifik samfundsmassig situation og som en proces, der hele tiden tenderer mod ændringer ( $\mathrm{L}$ af rance, 1983).

Men forst og fremmest er nærradio et praktisk fænomen, som, hvad enten det er opstået nedefra som et akut behov eller oppef ra som centralinitieret fors $\emptyset$, derfor har hårdt ved samtidig at skulle vare objekt for udforskning. Også dette var tydeligt på konferencen I Montreal, og det er tydeligt i Danmark under den gzal dende fors $\varnothing$ gsordning, som jo netop som fors $\phi g$ inkluderer udf orskning og central evaluering. 
En social proces, som narradiofors $\phi$ gene er udtryk for, stiller derfor en rakke forskningsmetodiske og - politisk/etiske problemer, som i det $\$ \phi l g e n d e$ skal indkredses for sa vidt angår en række helt centrale krydsf elter.

\section{Den mediedarwinistiske injektionsmodel}

Lad 100 radioer blomstre op, og lad os så se, hvad der sker. Nogenlunde sådan kan præmisserne for den danske nærradi of or $\$$ gsordning karakteriseres. Med henblik på at unders $\phi g e$, hvordan en permanent nærradio (og - tv) ordning bør struktureres, har man via lovgivningen abnet mulighed for, at stort set alle typer af narradio afprøves - ikke i første omgang som udtryk for et konstateret behov hos "brugerne", men hos lovgiverne, som i forl f

Uden at have præciseret hensigten yderligere udover at tilkendegive, at de nye radioer skulle supplere mediebilledet og udvide ytringsmulighederne, synes fors $\emptyset$ gsordningen derfor primart at sigte mod at undersøge, hvilke typer af radio, der pa langere sigt viser sig levedygtige: i hvor høi grad er de i stand til p\& lokal basis at etablere en rimelig kontinuert drift på et $\emptyset$ konomisk tilstr ækkeligt grundag uden mulighed for at anvende reklamer og sponsorvirksomhed. En tradi tionel følgeforskning omkring en sadan fors $\emptyset$ gsordning vil derfor primart interessere sig for, hvilke økonomiske modeller, der viser sig hol dbare, hvilke styringsstrukturer der forekommer mest optimale, og hvilken genlyd den enkelte radio $\mathrm{i}$ form af aktivitet og lyttertal giver i det pågæl dende lokalsamfund. Med de ressourcer, der i den danske fors $\emptyset$ gsordning er allokeret til denne udforskning af fors $\varnothing$ gene - og det det drejer sig om en halvtidsansat forsker og nogle fa 100-tusinde kroner til lytterundersøgelser-eksisterer der en oplagt fare for, at den dokumentation, der således materielt er grundlag for at oparbejde, vil føre til en overbetoning af sadanne kvantitative betragtninger over, hvem der er levedygtige: survival of the fittest.

Denne tendens spores allerede hos forskningsobjektet selv - radioerne - som i en bestr abelse pa at demonstrere levedygtighed for det forste i programlægningen skeler vel meget til lyttertal og for det andet bruger mange $k$ r fer ter alle mulige $\emptyset$ konomiske løsninger, hvoraf presset for at fa mulighed for at reklamere er den 
mest iøjnefaldende. Sådan måtte det gå med et forsøg, hvor der ikke fra starten har ligget klare forestillinger om netop finansieringen. Dette kan ikke klandres forsøgene, som er blevet bragt i denne situation, men det må ideelt vare følgef orskningens opgave mere nuanceret at analysere fors $\phi$ genes samlede udvikling ud fra kvalitative betragtninger, sa det ikke alene bliver markedsøkonomiske parametre, der bliver bestemmende for en kommende nærradio-ordning.

\section{Rekonstruktionen af den bor gerlige offentlighed}

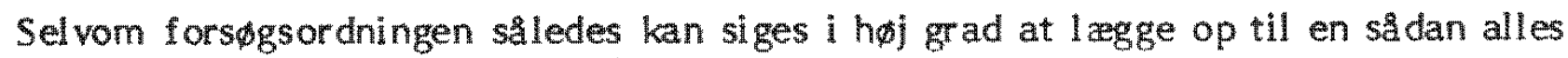
kamp mod alle om en plads i et kommende system, betyder det ikke, at der ikke ogsa implicit i fors $\emptyset$ gsordningen ligger en rakke kvalitativt betonede pr æmisser for, hvad man onsker eller forestiller sig, narradioerne vil kunne betyde i det lokale mediebillede.

Et væentligt element i public access-forestillingerne er konciperet i forhold til en traditionel opfattelse af den borgerlige offentligheds funktion. Dette galder Enzensbergers forestillinger om en retlinet politisering af de behov, som ligger bag massekulturens succes, og det ligger også bag central t-poli tiske forestillinger, som bl.a. udtrykkes 1 kravet om, at nærradioerne ikke må dubblere Danmarks Radios programmer, hvor der først og fremmest tankes $\mathrm{p}$ lokaliseringen af indholdet og placeringen af indholdet i traditionelle offentligheds former: den politiske og samf undsmassige debat, eller som kulturminister Lise $\emptyset$ stergaard under for $\$$ gslovens 1 . behandling udtrykte det:

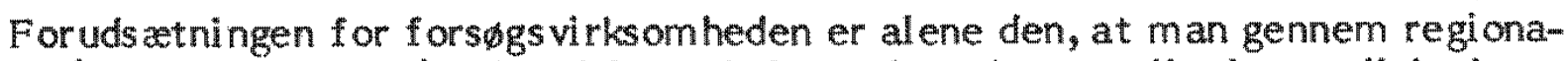
le (læs: lokale, O.P.) udsendelser skal supplere kommunikationsmulighederne inden for det lokale omrade, og at programvirksomheden må omfatte en sa alsidig behandling som muligt af lokale emner og problemer. (Folketingstidende, 1981, sp. 6233).

Det citerede indlæg, som langt fra udmarker sig ved et fortroligt forhold til rammerne for en fors $\phi$ gsordning som den danske, som netop ikke kræver alsidighed, pr aciserer implicit sit grundlag $I$ en traditionel forståelse af mediernes funktion $i$ den politiske offentlighed. 
Denne forståelse fremtræder skærpet 1 indl ægget fra det radikale venstre under behandlingen, hvor Jane Normann bl.a. fremhavede:

... at den sikreste måde at slå et godt projekt i stykker på er ved at lade nogle uprof essionelle lave det (...) det er al tsa en alvorlig advarsel mod at tro, at man bare popul art sagt kan lagge mikrofonen ud til lokalbef ol kningen og sige: værsgo at lave radio, og sa tro, at det bliver et eksperiment, vi kan fa glæede af. (Ibid.sp. 6231, jeg fremhæver, O.P.).

Udgangspunktet $i$ en traditionel borgerlighed offentlighed vil for politikere og andre planl aggere givet føre til skuffelse over en stor del af forsøgene, og i det omfang forsøgene selv er indfanget $i$ en sådan tankning, vil den hos disse føre til frustration. Skal nærradioen tages al vorligt som muligheden for al ternativer, er det indsnavrende at have den professionelle journalistik som malestok. Tværtimod betyder en udvidelse af ytringsfriheden i de elektroniske medier jo, at en afprofessionalisering biver mulig. Det er ikke langere nфdvendigt at lade journallstik-uddannede fortolke borgernes behov og problemer og fremstille dem for disse som forbrugere. Ligesom en kvantitativt orienteret markedsanalyse ikke alene kan godtgøre hvad der er succes og fiasko, kan heller ikke en traditionel offentlighedsforstålse yde nærradiobevægelsen retf ærdighed, for den handler om meget mere end en udvidelse af de traditionelle massemedier, som de er udviklet de sidste 100 ar som en sakkaldt 4. statsmagt - men bernærk, netop en magt, som er dybt infil treret i det politiske parnas' logik.

\section{Sam- og modvirkespiraler: kommunikation, disharmoni og dynamik}

Det er vigtigt at have kritiske og professionelle medier og mediearbejdere til at følge den samfundsmassige udvikling - og vi har jo alt for fa af sådanne, men nærradioernes opgave er ikke at løse dette problem for den bestående offentlighed. Skal narradioen vare eksemplet på af-massificering af medierne, må dette projekt tages alvorligt, og centrum for projektet ligger derfor hinsides denne problemstilling i sin snævre forstand.

Nærradioen er kun en af mange kanaler og former, hvori kommunikation og information flyder til og mellem individer og grupper $i$ et givet område, og netop 
kommunikationsprocesserne i deres mangfoldighed står derfor i centrum også i forbindelse med udf orskningen af nærradioerne.

Dette fremhaves i bogen "Samvirkespiralen. Människan i informations- og kommunikationsamhället" (Thunberg et al. 1979), hvor udgangspunket er en rakke problemer vedrørende uønsket social ulighed. Det fremhaves $\mathrm{i}$ bogen, hvordan mennesket forstå et som et malretttet og handlende individ kun opnår identitet og selvtillid gennem interaktion med andre, og kun herigennem opnår ressourcer til at deltage som subjekt i mikrom og makrosociale processer. Økonomiske, uddannel sesmaessige og andre forhold uomtalt, bliver kommunikationen derfor helt central 1 udviklingen af et samfund hen mod større lighed forstå et som lige muligheder.

Kommunikationsprocessen bestemmes $i$ bogen som havende 4 afg $\phi$ rende funktioner: en social (samvers) funktion, en ekspressiv funktion, en informations- og vidensopbyggende funktion og en kontrolfunktion, dvs. muligheden for at handle og pavirke i forhold til ornverdenen. Kun I de farreste tilf alde kan en kommunikationsproces siges at opf ylde alle funktioner p̊̊ én gang, og $\mathrm{f} x$ de traditionelle massemedier har jo en betydelig slagside til fordel for de abstrakte og ikke-handlingsorienterede funktioner.

1 det forfatterne kalder en samvirkespiral, er det imidlertid afgørende, at de 4 funktioner alle indgår som vasentlige elementer, for di det kun herved bliver muligt for den enkel te at handle socialt og forstå sig selv som handlende.

Omend bogens grundlag er hildet $i$ en rationalistisk menneskeforståelse, påpeger det opstillede paradigme, hvordan fx narradioen ikke blot kan betragtes som snævert medium, men må ses som led i sociale og kommunikative processer, der kan befordre den enkel tes demokratiske og personlige udf oldel sesmuligheder og p\& dennes egne pr æmisser. Konkluderende hedder det derfor:

Accepterer man ræsonnementet or, at samvirkespiralen ma udvikles i del tagernes eget sprog, har man samtidig påpeget, hvad målet må være, hvis man i større malestok vil angribe det herskende kommunikationsherredømme. Den ligevardige kommunikation som skal erstatte kommunikationsherredømmet, må bestå i kommunikationsmangfoldighed. Det egalitære (jämlika) samfund karakteriseres af massevis af samvirkespiraler, udformet i deltagernes eget sprog og ud fra deres egen kul tur. (Thunberg et al. 1979: 88). 
Skal narradioen betragtes ikke som noget i sig selv, men som en del af sociale og kommunikative udviklingsprocesser, er hermed ogsa angivet, hvordan en udforskning af narradioforsøget vil have sine centrale foci i en bred undersøgelse af sådanne processer, som ikke alene kan belyses i snaver relation til den enkelte radios gkonomi, indhold og lyttertal.

Forstå som samvirkespiraler vil narradioen derf or bl a, udtrykke en kommunikativ "re-privatisering" eller ikke-professionel tilegnelse af et socialt redskab, og feltet for narradio-aktiviteten vil som noget centralt vaere karakteriseret af samog modvirkespiraler både i sin egen udvikling, i forhold til de eksisterende medier og 1 forhold til mangfoldigheden af sociale processer. Eller sagt pa en anden made: narradioen forstaet som samvirkespiral betyder, at den er karakteriseret som proces og dynamik. En 1 lglgeforskning, som forsøger at gribe denne proces og analysere den (og det er opgaven), stå 1 fare for at stoppe den, hvis ikke netop processualiteten og dermed uforudsigeligheden far en central plads i analysen.

\section{Aktionsforskningen og normativitets dilemmaet}

Det er en velkendt socialvidenskabelig lovmassighed, at ogede ressourcer alt andet lige 1 i 1 rste omgang anvendes af de sakaldte ressourcestarke grupper i samfundet. Det gælder $\not g e t$ information, og det gæl der naturligvis ogsa $\emptyset$ gede adgangsmuligheder til medierne. At stille sendemuligheder til radighed for et givet lokalt samfund betyder derfor ikke, at alternativer opstår af sig selv, hverken mht. hvilke befolkningsgrupper, der anvender de nye muligheder eller $\mathrm{mht}$. form og indhold:

Tilstedevarelsen af "frie" radioer udgor vomtvisteligt et institutionelt al ternativ relativt til monopoleme, men det betyder ikke samtidig, at der hermed skabes al ternative praksisformer.

Denne kendsgerning, her citeret efter Mattelart og Piemme (1980), vidner en lang rakke forsøg i såvel Vesteuropa, Nordamerika og på det seneste ogsa $\varnothing$ steuropa om (Szekfu, 1984).

Lokalmedier er ikke i sig selv nok till at skabe grundlag for adgang til og deltagelse i medieme for den store del af befolkningen. Faktisk anvendes disse 
medier of te til den tradi tionelle form for hierarkisk kommunikation...

Saledes konkluderedes det i forbindelse med en international konference om narmedier i 1977 (Jouet, 1977: 38).

I en rakke tilfalde skyldes denne udvikling omklamringen fra den traditionelle journalistik eller aspirationen om en sadan, og $\mathrm{i}$ andre det faktum, at forsøgene ikke far lov til eller mulighed for at udvikle sig i sin egenlogik og-rytme som $f x$ de engelske lokal-t v-fors $\phi g$ i 1970-eme (cf. Prehn, 1981).

Fors $\phi$ gene med narmedier er eksperimenter med sociale processer, og fors $\phi$ gene og den tilknyttede $f \emptyset l g e f o r s k n i n g$ har derfor mere eller mindre bevidst og radikalt karakter af aktionsforskning. Aktionsf orskningens primare opgave er at medvirke til, at forskningsobjektet inddrages $i$ udforskningen og den udforskede proces $i$ en sådan grad, at objektet bliver processens subjekt.

En sådan forskningsstrategi indebærer naturligvis en lang række både metodiske, teoretiske og ikke mindst forskningspolitiske/etiske problemer mht. pa den ene side forskningens loyalitet med det udforskede og pa den anden side samme forsknings videnskabelige integri tet.

Disse overordnede problemer skal ikke berøres narmere I denne sammenhang, og der henvises derfor til behandlinger heraf hos Haag et al. 1972 og Cremer og Klehm, 1978.

Problemet er klart som navnt et loyalitetsproblem i den forstand, at forsknings processen bliver en del af selve det sociale eksperiment med den hensigt at fremme nogle og hæmme andre udviklingstendenser. Forskningen er på én gang indeholdt i processen og samtidig uden for den og derfor hele tiden p\& kollisionskurs $i$ forhold til praktikerne (cf. fx M. de Bruin et al. 1982).

Men modsætningerne antager ogs\& karakter af et normativitets-dilemma $i$ eksperimenter, hvor målet ikke er pracist defineret - og det er det ikke, når centrum er processen: 
Når jeg siger mobilisere, så mener jeg mobilisere (...) at gøre menneskene bevægeligere end de er. Frie som dansere, åndsnærværende som fodboldspillere, overraskende som guerillos

fremhaver Enzensberger i sin medieteori (Enzensberger 1974 (1970). Omend projektet for Enzensberger var massernes politisering og mobilisering, vidner metaforerne om en multifunktionel mobilisering og dermed samtidig om en storre grad af uforudsigelighed, end Enzensberger selv pr æciserede. Men samtidig mere præcist end måske tilsigtet peger Enzensbergers metaforer på områderne kunst, selvudfoldelse, kampen, konkurrencen, med- og modspil og det politiske slagsmål. At op-have begrebet massemedier til massernes medier er netop at ophæve den borgerlige offentligheds bornerte grænser, at af prof essionalisere og ekskommunikere massernes stedfortr ædende repr asentanter 1 kommunikationshierarkiets herredømmestruktur.

For en aktionsrettet folgeforskning er det centralt at medvirke til en aben og fordomsiri analyse af disse brud, men samtidig at undga at forfalde til ren eftersnakkende relativisme. At forholde sig til dette dilemma er at opretholde forskningens kri tisk-analyserende potentiale.

Et eksempel på dette dilemma er netop public access teorien i sig selv, som i sin mere snævre udgave ligger parallelt med såkaldt erfaringspædagogiske overvejelser, hvor grænseløs loyalitet med det enkel te individ som al tings udgangspokt tendentielt kan føre til autisme og udgr ansning fra omverdenen.

Saledes navnes det fx i Auer et al. 1980 (pp. 168-69):

De fleste informationer i fjernsynet stammer fra en verden, som man ikke selv erfarer og derfor ikke kan relatere til sig selv. Herved forhindres kommunikation. Gennem videoarbejde kan den direkte kommunikation, som på mange områder bliver mere og mere begr anset, fremmes og realiseres. Kommunikationen bliver vigtigere end mediet.

Narmedier, public access etc. kan naturligvis udvikle sig til en uf rugtbar, eskapistisk lokal-autisme, som ikke ligger langt fra massemediernes psyko-sociale funktioner. 
En aktionsforskning på et kvalitativt grundlag må derfor samtidig analysere de dybereliggende bevagggrunde og funktioner for at kunne danne sig et billede af nye kommunikationsmuligheders og -strukturers betydning.

Aktionsf orskningens dilemma er derf or på den ene side loyalt at skulle analysere sit genstandsområde, men på den anden side ikke i misforstaet loyalitet at opgive sit kritiske potentiale som politisk aktionsforskning. Den konfliktmodel, som nærradioforsøgene udspiller sig inden for, bliver derfor også forskningens konflikt.

\section{En proaktiv, policyorienteret lgeforsking}

De problemstillinger og krav 1 forbindelse med folgeforskning omkring nærradioforsøgene og tilsvarende eksperimenter af lokalgeografisk eller på anden måde begr zenset tilsnit kan naturligvis ikke alle tages op - og slet ikke tilfredsstillende af en central følgeforskning som den danske. En egentlig følgeforskning forstået som aktionsforskning ma være decentral og tat knyttet til det enkelte eksperlment.

Dette betyder naturligvis ikke, at den centrale forskning skal opgive at forfølge de centrale problemstillinger, som ovenfor er berørt.

Som det fremgår i den foregånde artikel, hvori bringes en række resultater og overvejelser i for bindelse med de første centrale unders $\phi$ gelser af nzerradi of ors $\phi g e-$ ne, kan man allerede $\mathrm{i}$ dag se tydelige tendenser $\mathrm{i}$ udviklingen af forskellige radiotyper med forskelligt gennemslag målt på lyttertal. Samtidig kan man se tegn på selvstændige genreudviklinger, som blander forskellige hidtil adskil te radioprogramtyper, og endelig ses mere eller mindre tiltalende og overbevisende fantasifuldheder i forbindelse med stationernes uf orskyldte qkonomiske problemer. Og sidst men lkke mindst: fors $\phi$ gsordningen har vist en overordentlig stor bredde social t og pa anden vis i stationernes rekrutteringsgr undlag.

Der er derfor al grund til at tro, at de danske narradiofors $\emptyset g$ vil kunne bibringe dels konkrete erfaringer omkring en lokal stations drift og funktionsma de og mere generelt omkring public access og selviorval tning. 
Når dette er sagt må det imidlertid atter fremhæves, at omend det fors $\phi$ gsmæssige materiale således er tilstede, kniber det med at kunne analysere og dokumentere udviklingen, fordi fors $\emptyset$ gsordningens finansielle og på anden måde rssourcemassige gr undlag ikke sikrer tilstr ækelig følgef orsking.

Den centrale følgeforskning er derfor tvunget til dels at koncentre sine kr æf ter på enkel tområder og på mere generelle iagttagelser vedr ørende økonomi, strukturer, indhold og lytter grundlag.

De ovenfor anførte krav til følgeforskningen bør holdes for $\phi j e ~ i$ analysen af fors $\varnothing$ genes udvikling.

Fors $\phi$ gsordningen og dermed den centrale f $ø$ lgef orskning sigter mod at til vejebringe og artikulere et erfaringsgrundlag for en permanent lovgivning. Følgeforskningen er derfor som næunt $\mathrm{i}$ dobbelt forstand aktionsforskning: dels i forhold til fors $\varnothing$ genes udvikling i løbet af forsøgsordningen og dels i forhold til de politiske beslutningsprocesser.

Folgef orskningens opgave (og lokal radiom og-tvudvalgets for den sag skyld) med at pege på permanente modeller vil ikke blive nogen simpel opgave. Dels er der tale om meget forskelligartede fors $\phi g$ bade hvad angår hensigt og struktur, som man ikke blot kan valge imellem, men eventuelt ma sikre forsat eksistens i mere eller mindre modificeret form, og dels vil en rakke problemer specielt omkring de finansielle spørgsmal ikke kunne belyses direkte ud fra forsøgene, som økonomisk i фjeblikket hel $\mathrm{i}$ modstrid med dansk tradition mest ligner ordningen I USA, hvor det er forbudt at reklamere, og hvor man derfor er henvist til frivillige bidrag, hvilket er $\mathfrak{i}$ overenssternmelse med den der herskende tradition omend ikke ukompliceret (ca. 25\% af arbejdstiden går med at skaffe penge), mens dette ikke er tilf æl det i Danmark.

To lette løsninger byder sig til: at frigive reklamer og dermed skabe grobund for det, nærradioerne i USA er et alternativ til, eller en mere eller mindre restriktiv ordning med udgangspunkt i de lokale politiske cirkler eller som i Sverige centreret omkring eksisterende foreningsdannelser med penge i ryggen. 
Det er for tidligt på grundlag af forsøgenes udvikling og erfaringer at sige noget præcist om en kommende ordning, men det må i forlængelse af ovenstånende problemstillinger være værd at præcisere det vigtige $i$, at følgeforskningen ikke forfalder til lette løsninger, men tvartimod stiller spørgsmalstegn, hvor der er behov for og rimelighedi det.

Hvis folgeforskningen skal gribe processen uden at stoppe den, dvs. tematisere forsøgenes erfaringer $i$ en retning, sa en permanent ordning fremmer og ikke hæmmer en fortsat dynamik, ma folgeforskningen forstå sig ikke blot som aktionsforskning, men også som en slags proaktiv vurdering af eksperimenternes forløb og muligheder.

I den I indledningen omtalte bog af Ithiel de Sola Pool, konstateres det (lidt forkortet), at de nye teknologier i sig selv rummer muligheden for frig ørelse, og kun forkerte politiske beslutninger vil kunne forhindre en sådan (Pool, 1983: 231).

Sola Pool ser $\mathrm{i}$ sin analyse af kommunikationsteknologierne storsindet bort fra en rakke sociale parametre, som gør en sådan frigørende eller $i$ hvert fald fri udnyttelse af medierne mindre indlysende i fald de kastes p\& det almindelige okonomiske marked, men korrekt er det, at nye medier kraver nye politikker. Udgangspunktet for en ny politik for de elektroniske nærmedier er erfaringerne fra fors $₫$ gene forstået som sociale og kommunikative processer. Hensigten med nærmedierne må være at nå s̊ langt som muligt i retningen af at realisere den materielle ytringsmulighed for s̊ mange som muligt p̊̊ deres egne vilkår, og forsøgsordningens erfaringer vil derfor ikke blot pege på snævert styringspolitiske til tag I forbindelse med en permanent lovgiming, men i lige så høj grad på eksterne problemer i forbindelse med de privatkapitalistiske mediers rolle i forhold til narmedierne, de uddannelsespolitiske perspektiver $i$ forbindelse med en radikal udvidelse af ytringsmulighederne, den offentlige forval tningspraksis stillet over for ikke blot professionelle men også uprof essionelle mediearbejdere etc.

Som centrum for sociale processer i lokalsamfundet rækker nærradioerne derfor langt omkring, og det er derfor vigtigt at gentage den gamle læresætning bade for fors $\phi g e n e$ og den forskning, som følger dem, at centrum for lokalforsøgene ligger uden for forsøgene selv. 


\section{Referencer}

Auer, Sepp et al .: Arbeiter machen Fernsehen. Graz 1980.

de Bruin, Marjan et al.: Media participationt a possible perspective for community broadcasting. Amsterdam 1982 (stencil).

Cremer, Christa \& W.R. Klehm: Aktionsforschung. Weinheim/Basel 1978.

Enzensberger, Hans Magnus: Bygges at til en medieteori. In: Thygesen (ed.) Folkets Røst. Kbh. 1974.

Haag, Fritz et al.: Aktionsforschung. München 1972.

Jouet, Josiane: Community Media and Development: problems of Adaption. Paris 1977.

Laf rance, Jean-Paul: Community Oriented Broadcasting Throughout the World. A Preleminary Appraisal. Montreal 1983.

Lewis, Peter: Community Radio: The Montreal Conference and After. In: Media, Culture and Society, 1984, 6.

Mattelart, Armand \& J-M. Piemme: New Means of Communication: new questions for the left. In: Media, Culture and Society, 1980, 2.

Pool, Ithiel de Sol a: Technologies of Freedom. Cambridge/Ma \& London 1983.

Prehn, Ole: Lokal-tv. 1970ernes erfaringer i England og Danmark. Aalborg 1981.

Prehn, Ole: The World Conference of Community Oriented Broadcasters. Rejserapport. Småskrifter om lokalradio og-fjernsyn. 2. Aalborg 1983.

Szekfü, András: The First Experiment in Community Cable TV in a Socialist Country. Budapest 1984.

Thunberg, Anne-Marie et al.: Samverkanspiralen. Stockholm 1979.

Ole Prehn er seniorstipendiat ved A alborg Universi tetscenter. 